\title{
cAMP and PMA enhance the effects of IGF-I in the proliferation of endometrial adenocarcinoma cell line HEC-1-A by acting at the $G_{1}$ phase of the cell cycle
}

\author{
F. Talavera, C. Bergman, M. L. Pearl, P. Connor, J. A. Roberts and \\ K. M. J. Menon
}

Department of Obstetrics and Gynecology, University of Michigan Medical Center, Ann Arbor, Michigan, USA

(Received 18 October 1994; revision accepted 23 January 1995)

\begin{abstract}
The present study was undertaken to determine whether endometrial cancer cell line HEC-1-A differ from nontransformed cells, in that the cAMP and protein kinase $C$ pathways may enhance IGF-I effects in mitogenesis by acting at the $G_{1}$ phase of the cell cycle instead of $G_{0}$. Immunofluorescence staining of HEC-1-A cells using the proliferating cell nuclear antigen (PCNA) monoclonal antibody and flow cytometric analysis determined that HEC-1-A cells do not enter the $G_{0}$ phase of the cell cycle when incubated in a serum-free medium. Approximately $51 \%$ of the cells were in $\mathrm{G}_{1}, 12 \%$ were in $\mathrm{S}$ and $37 \%$ in $\mathrm{G}_{2}$ phase of the cell cycle prior to treatment. Forskolin and phorbol-12-myristate 13-acetate (PMA) were used to stimulate cAMP production and protein kinase $C$ activity, respectively. IGF-I, forskolin and PMA each increased $(P<0.01)\left[{ }^{3} \mathrm{H}\right]$-thymidine incorporation in a dose and time dependent manner. The interaction of forskolin and PMA with IGF-I was then determined. Cells preincubated with forskolin or PMA followed by incubation with IFG-I incorporated significantly more $(P<0.01)\left[{ }^{3} \mathrm{H}\right]$-thymidine into DNA than controls or any treatment alone. It is concluded that forskolin and, to a lesser extent, PMA exert their effect at the $G_{1}$ phase of the cycle to enhance IGF-I effects in cell proliferation.
\end{abstract}

Insulin-like growth factor-I (IGF-I) is known to elicit a mitogenic response in vitro and in vivo in a variety of normal and neoplastic cells (Sell et al. 1993, Pietrzkowski et al. 1992, Dickson et al. 1987, Tricoli et al. 1986). Mitogenesis, however, is a multistep process where a competence signal stimulates the cells to traverse the $\mathrm{G}_{0} / \mathrm{G}_{1}$ phase of the cell cycle, and progression factors such as IGF-I then commit the cell to DNA synthesis. For example, studies performed with mouse embryo have shown that the EGF receptor requires the presence of a functional IGF-I receptor for its mitogenic and transforming activities (Coppola et al. 1994). In addition, studies with Balb C/3T 3 cells, have shown that quiescent fibroblasts do not respond mitogenically to EGF unless they have been pretreated with cAMP analogs (Olashaw et al. 1988). Similarly, in FRTL-5 cells, a line of nontransformed rat thyroid cells, the effects of IGF-I on [ ${ }^{3} \mathrm{H} \mid$-thymidine incorporation have been shown to be significantly enhanced by prior exposure to cyclic AMP (Tramontano et al.

Correspondence: Dr K. M. J. Menon, Dept. of Ob/Gyn, 1500 E. Medical Center Drive, L1221 Women's Hospital, University of Michigan Medical Center, Ann Arbor, MI 48 109-(2)278, USA. 
1988). However, cells from primary carcinomas, as well as established cancer cell lines, differ from normal cells, in the sense that cancer cells arrest in the $G_{1}$ phase of the cell cycle instead of $G_{10}$ during density inhibition or serum deprivation (Tay et al. 1991). Therefore, factors such as cAMP or protein kinase $\mathrm{C}$ which are known to play a competence role in various cell systems. would not act in cancer cells to recruit them from the $G_{0}$ phase into the cell cycle but instead enhance the mitogenic activity of growth factor stimulated cells by acting at the $G_{1}$ phase of the cell cycle.

We have been studying the growth regulation of transformed cell line HEC-I-A which is derived from endometrial adenocarcinoma (Pearl et al. 1993). This cell line possesses type I IGF receptor (Perkonen et al. 1991) and IGF-I stimulates both $\left[{ }^{3} \mathrm{H}\right]$-thymidine incorporation and cell growth as evidenced by an increase in cell number (Talavera et al. 1992). Furthermore, treatment of this cell line with PMA and forskolin also stimulates mitogenesis, suggesting that protein kinase $\mathrm{C}$ and cyclic AMP mediated cellular mechanisms might trigger the growth of these transformed cells (Talavera et al. 1992). The purpose of the present study was to examine whether protein kinase $C$ and cyclic AMP would act at the $G_{1}$ phase of the cell cycle to further enhance IGF-I effects in the mitogenic activity of endometrial adenocarcinoma cell line HEC-1-A.

\section{MATERIALS AND METHODS}

Recombinant IGF-I was a generous gift from Eli Lilly Research Laboratories (Indianapolis, IN. USA). Fatty acid free bovine serum albumin (BSA), fetal bovine serum (FBS), phorbol 12myristate 13-acetate (PMA), forskolin, 8-bromo cAMP, and 1 oleoyl-2-acetyl glycerol (OAG) were obtained from Sigma Chemical (St Louis, MO, USA). H-stain (Hoechst, 33258 dye) was purchased from Aldrich (Milwaukee, WI, USA). Electrophoresis reagents and trypsin/EDTA solution containing $0.25 \%$ trypsin and $0.02 \%$ EDTA, were obtained from BioRad (Richmond, CA, USA).

\section{Cell cultures}

Human endometrial cancer cell line HEC-1-A (ATCC \#HTB-112 batch \# F-6720) was purchased from the American Type Culture Collection. The cells were maintained in DME/F 12 mixture (Sigma D2906) supplemented with $10 \%$ fetal bovine serum, $50 \mu \mathrm{g} / \mathrm{ml}$ gentamycin, and $2 \mathrm{U} / \mathrm{ml}$ nystatin. The cells were cultured in $75 \mathrm{~cm}^{2}$ tissue culture flasks (Corning Glass Works, Corning, NY, USA) and maintained at $37^{\circ} \mathrm{C}$ in a water saturated air with $5 \% \mathrm{CO}_{2}$. For subculturing, the medium was removed and replaced with fresh buffer containing $0.25 \%$ trypsin and $0.02 \%$ EDTA solution. After $2 \mathrm{~min}$, the solution was removed and the flasks maintained at $37^{\circ} \mathrm{C}$ for approximately $10 \mathrm{~min}$ to allow the cells to detach. The cells were suspended in fresh medium and centrifuged at $150 \times \mathrm{g}$ for $10 \mathrm{~min}$. The supernatant was discarded, and the cell pellet resuspended in fresh medium. The resuspended cells were cultured in 24 well plates and incubated in scrum-free DME medium $(0.3 \% \mathrm{BSA})$ for $24 \mathrm{~h}$ to allow for cell attachment. Following this incubation, the cells were treated immediately as described in the figures. Given the aggressive growth of these cells in serum-free medium, possibly due to autocrine growth factors being secreted by the cells, initial results were often inconsistent regarding the magnitude of their response to growth promoting agents. However, we have found that a consistent response to growth factor stimulation is observed when the cells are washed extensively (three times) with serum-free medium prior to treatment and when the cells are treated $24 \mathrm{~h}$ following their initial plating in the absence of serum. These conditions were used for all incubations in our studies. 


\section{Immunofluorescence staining of HEC- 1 -A cells}

The endometrial HEC-1-A cells were removed from the wells with fresh buffer containing $0.25 \%$ trypsin and $0.02 \%$ EDTA solution, as described above, for subculturing and washed in PBS. The cell pellet was resuspended in $500 \mu \mathrm{l}$ of a solution containing $1 \%$ paraformaldehyde, vortexed and incubated for $20 \mathrm{~min}$. Following a wash with PBS, the cells were then mounted on a microslide for fluorescent microscopic observation (Menge et al. 1993). The fixed cells were incubated with $200 \mu \mathrm{l}$ containing $20 \mu \mathrm{g} / \mathrm{ml}$ of mouse proliferating cell nuclear monoclonal antibody (PCNA IgG 2 : Oncogene Science, Uniondale, NY, USA). Negative controls were incubated in the presence of mouse $\operatorname{IgG}_{2 \mathrm{a}}$. The cells were then washed with $2 \mathrm{ml}$ of PBS and incubated with $200 \mu \mathrm{l}$ of a second antibody (anti $\operatorname{lgG}_{2 a}$ ) labelled with fluorescein isothiocyanate (FITC: Dako, Carpinteria, CA, USA). Slides were examined using a Fluorescence microscope (Carl Zeiss, Germany).

To analyse for the presence of the cell cycle dependent protein $\mathrm{Ki}-67$, the immunofluorescence analysis was carried out as described by Coltrera and Cown (1991). In brief, the cells were fixed using absolute methanol for $30 \mathrm{~min}$. The fixed cells were incubated with $200 \mu 1$ of mouse Ki-67 antibody (Dako Corporation, Santa Barbara, CA, USA) at $1: 25$ dilution. The cells were then washed with $2 \mathrm{ml}$ of PBS and incubated with $200 \mu \mathrm{l}$ of Fluorescin-conjugated (FITC; $1: 100$ ) goat anti-mouse anti-IgG (Fc specific), purchased from Sigma Chemical (St. Louis, MO, USA). The antibodies were diluted with PBS containing 1\% BSA.

\section{Flow cytometry and cell cycle analysis}

Cells were plated at a density of 50000 cells/well in DME, incubated with bromodeoxyuridine (BrdUrd; $10 \mu \mathrm{M}$ ) for $30 \mathrm{~min}$ prior to harvesting and processed for indirect immunofluorescence staining as described by the manufacturer (Beckton Dickinson Immunocytometry Systems, San Jose, CA, USA). Processed cells were analysed using an Elite Flowcytometer (Coulter Corporation, Hialeah, FL, USA) fitted with an Argon lon Laser adjusted to emit $15 \mathrm{~mW}$ at $488 \mathrm{~nm}$. Green fluorescence was measured through a BP $525 \mathrm{~nm}$ filter. Propidium iodide red fluorescence yielded cell cycle distributions unaffected by BrdUrd incorporation and was measured through a BP $630 \mathrm{~nm}$ filter. The bivariate fluorescent distributions were displayed in dot blots $(64 \times 64$ channel array). Each analysis was carried out on at least 10000 events and an analysis region was placed on the dual parameter histogram of the isotype control, so that $5 \%$ of the cells in the control sample were located in the region. Any sample giving a signal of greater than $5 \%$ above the control was considered positive. Compartmentalization of the cell cycle was analysed on an Epics Elite Workstation (Coulter Corporation).

\section{Thymidine incorporation assay}

Thymidine incorporation studies were performed in 24 well plates (Imai et al. 1982). Cells were plated at a density of 50000 cells/well in DME and treated for $24 \mathrm{~h}$ intervals, unless specified otherwise. Four hours prior to completion, $1 \mu \mathrm{Ci}\left[{ }^{3} \mathrm{H}\right]$-thymidine was added to each well. Cells were then washed with ice cold PBS and incubated with TCA (5\%) to remove the acid soluble $\left[{ }^{3} \mathrm{H}\right]$-thymidine pool. Cells were washed again with $\mathrm{PBS}$ and dissolved in $500 \mu \mathrm{l} \mathrm{NaOH}(0.2 \mathrm{M})$ to recover the remaining incorporated $\left[{ }^{3} \mathrm{H}\right]$-thymidine. This was transferred to scintillation vials containing $10 \mathrm{ml}$ Biosafe 11 . After neutralization with $0.2 \mathrm{~N} \mathrm{HCl}$, the radioactivity was determined using a beta particle counter.

\section{Cell growth assay}

HEC-1-A cells (50000 cells/well) were plated in quadruplicate in 24 well plates containing $500 \mu \mathrm{l}$ phenol red-free DME/F 12 medium containing $0.3 \% \mathrm{BSA}$ in the absence or presence of 
various treatments. Following the incubations, the cells were harvested with $500 \mu$ lrypsin/EDTA solution, as described for cell cultures. The trypsin was neutralized with $500 \mu \mathrm{l}$ fresh medium. The cell number was quantitated in four aliquots from each replicate using a hemocytometer.

\section{IGF-I binding assay}

IGF-I iodination and binding assays were carried out as described previously (Talavera $e t$ al. $1990)$ with slight modifications. Briefly, cells were incubated with treatments as described in the figures. At the end of the treatment period, cells were washed and incubated with medium containing ${ }^{125} 1$-IGF-I in the absence or presence of a 200 -fold excess of unlabelled ligand. Incubations were performed at $4^{\circ} \mathrm{C}$ for $16 \mathrm{~h}$. Unbound growth factor was removed with ice-cold growth medium wash. Cells were then lysed with $0.5 \mathrm{~N}$ sodium hydroxide and incubated at $37^{\circ} \mathrm{C}$ for $30 \mathrm{~min}$. The radioactivity was quantitated in a gamma counter. Specific binding was determined by subtracting the nonspecific binding from total binding.

\section{DNA assay}

HEC-1-A cells were cultured as described for the growth assay. DNA was analysed by the procedure of Labarca \& Paigen (1982). The cells were solubilized with $0.25 \mathrm{ml}$ of $0.5 \mathrm{~N}$ sodium hydroxide and incubated at $37^{\circ} \mathrm{C}$ for $1 \mathrm{~h}$. High-salt DNA assay buffer $(0.75 \mathrm{ml}, 0.5 \mathrm{~m}$ sodium phosphate, $2 \mathrm{M}$ sodium chloride, $\mathrm{pH} 7.4)$ and bisbenzimidazole $(32 \mu \mathrm{g} / \mathrm{ml})$ were added and the $\mathrm{pH}$ adjusted to 7.2-7.4 with $0.5 \mathrm{~N}$ hydrochloric acid. DNA standards were prepared using calf thymus DNA. Fluorescence was measured at wavelengths set at $356 \mathrm{~nm}$ (excitation) and $458 \mathrm{~nm}$ (emission).

\section{Statistical analysis}

The data represent the mean \pm SEM of the number of determination analysed by ANOVA and a Student's $t$-test to compare differences among treatment groups. Each experiment was repeated at least four times.

\section{RESULTS}

\section{Expression of PCNA on HEC-1-A cells and flow cytometric analysis}

Initial studies were performed to determine the percentage of cells that were not in the $G_{0}$ phase of the cell cycle through immunohistochemical studies using the monoclonal antibody to PCNA. This antibody is not taken up by cells that are either in $G_{0}$ or $M$ phase of the cell cycle. Figure 1 shows the cells observed under fluorescent light. The percentage of cells staining positive for PCNA was $100 \%$, suggesting that the cells were not in $G_{0}$ phase of the cell cycle when treated. Negative controls that were incubated in the presence of mouse $\operatorname{lgG}_{2 \mathrm{a}}$ did not stain (data not shown). Some cells exhibited more fluorescent light than others which is consistent with cells that are found at different phases of the cell cycle.

To further confirm our observations that these cells do not exit to the $G_{0}$ phase when incubated in the absence of serum, the cells were analysed for the presence of $\mathrm{Ki}-67$ protein which is known to be expressed throughout the cell cycle but not in the $G_{0}$ phase. In order to examine this, the cells were either plated at a density of $50000 \mathrm{ml}^{-1}$ (low density), or grown to a density arrested state (high density) and incubated in the absence of serum $(0.3 \%$ BSA) for $24 \mathrm{~h}$ prior to the analysis. Figure $2 \mathrm{a}$ shows the staining of cells plated at low density. Figure $2 \mathrm{~b}$ shows the staining of cells that were density arrested prior to the analysis. Some cells exhibited more fluorescence than others. However, the percentage of cells staining positive for $\mathrm{Ki}-67$ was $100 \%$ for both low and high density plating suggesting that HEC-1-A cells do not exit to $G_{0}$ when they 


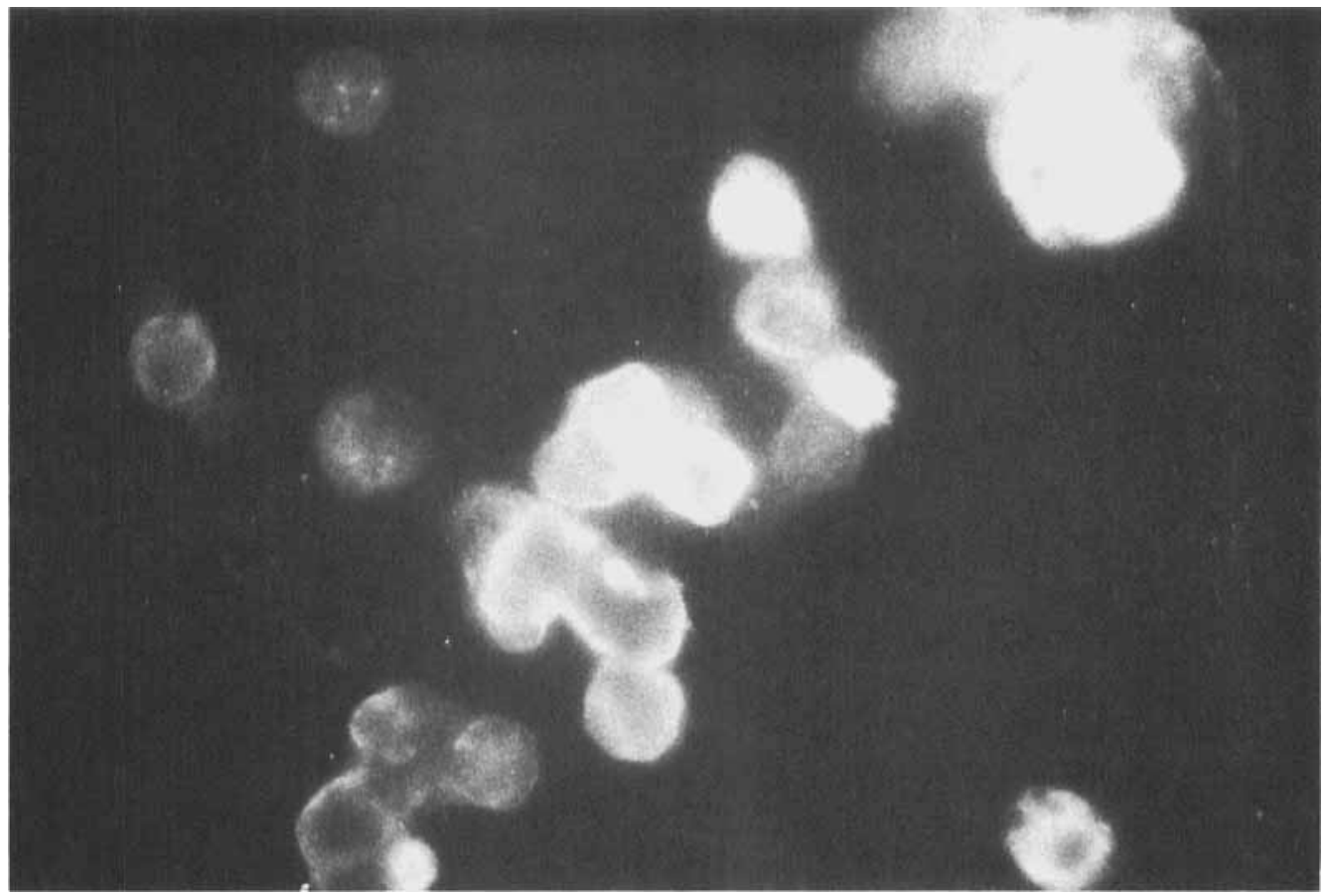

Figure 1. PCNA expression in HEC-1-A cells as identified by indirect immunofluorescence. Cells were grown to confluency and subcultured into 24 well plates for $24 \mathrm{~h}$ in the absence of serum. Following this incubation, the cells were harvested and analysed through immunostaining as described in the Materials and Methods section.

a
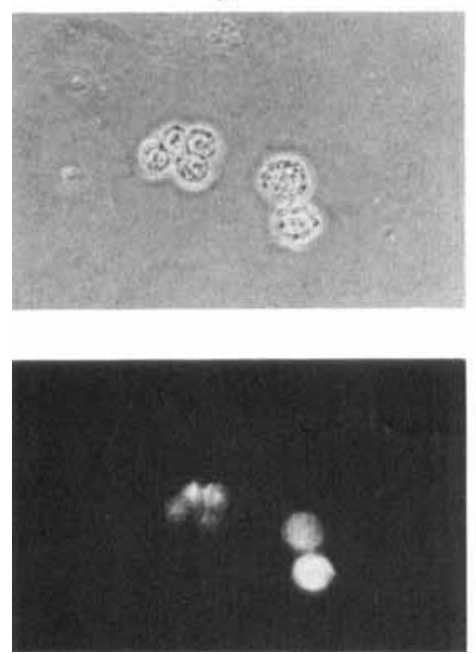

b
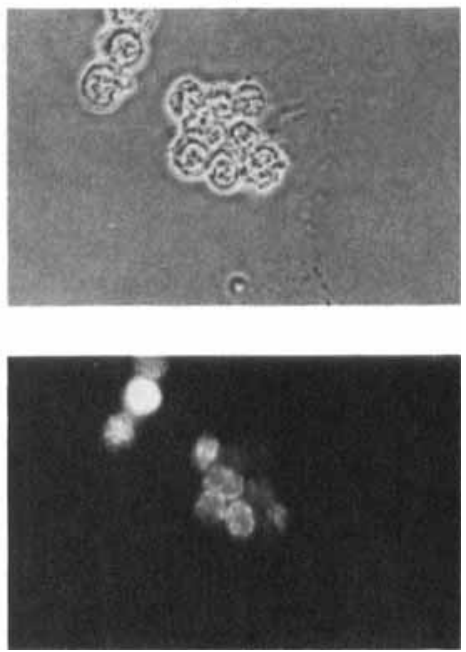

Figure 2. Ki-67 expression in HEC-1-A cells as identified by indirect immunofluorescence. a Cells were plated at $50000 / \mathrm{ml}$ and incubated in the absence of serum for $24 \mathrm{~h}$. b Cells were density arrested and incubated in the absence of serum for $24 \mathrm{~h}$. Following this incubations, the cells were harvested and analysed through immunostaining as described in the Materials and Methods section. 
are incubated in the absence of serum and density arrested. As expected, controls that were incubated with mouse $\operatorname{IgG}_{2 a}$ alone did not exhibit fluorescence (data not shown).

When nuclei from HEC-1-A cells were analysed for cell cycle phase distributions based on DNA content using flow cytometry, the results show that approximately $51 \%$ of the cells were in the $G_{1}$ phase of the cycle (Table 1). These results demonstrate that HEC-1-A cells continue to grow and do not enter the $G_{0}$ phase of the cell cycle when incubated in the absence of serum.

\section{Effect of IGF-I, forskolin and PMA on [ [ $\left.{ }^{3} \mathrm{H}\right]-$ thymidine incorporation}

Initial studies were performed to examine the time course of IGF-I effect on $\left[{ }^{3} \mathrm{H} \mid\right.$-thymidine incorporation in the endometrial adenocarcinoma cell line $\mathrm{HEC}-1-\mathrm{A}$. The cell exhibited a $32 \%$ increase $(P<0.05)$ in thymidine incorporation during the first $12 \mathrm{~h}$ of incubation and a maximum increase $(P<0.01)$ was observed at $24 \mathrm{~h}$ (data not shown). A $50 \%$ increase $(P<0.01)$ in $\left.\mid{ }^{3} \mathrm{H}\right)$ thymidine incorporation was observed with $100 \mathrm{ng} / \mathrm{ml}$ of IGF-I (Table 2).

The effects of forskolin and the tumour promoting phorbol ester, PMA, on $\left[{ }^{3} \mathrm{H}\right\}$-thymidine incorporation were also tested. Our initial studies showed that a minimum of 12 and $24 \mathrm{~h}$ incubation were required for forskolin and PMA, respectively, to stimulate $\left|{ }^{3} \mathrm{H}\right|$-thymidine incorporation significantly $(P<0.01)$. A maximum increase was observed at $24 \mathrm{~h}$ in response to both compounds (data not shown). The optimum increase $(P<0.01)$ was observed with $10 \mu \mathrm{M}$ forskolin and $10 \mathrm{nM}$ PMA $(P<0.01$; Table 2$)$.

\section{Effect of forskolin and PMA priming on IGF-I stimulation of $\left[{ }^{3} \mathrm{H}\right]-$ thymidine incorporation}

Experiments were performed to determine the effect of preincubation of HEC-1-A cells with forskolin and PMA on IGF-I stimulation of $\left[{ }^{3} \mathrm{H}\right]$-thymidine incorporation into DNA. In these studies, the cells were cultured for $24 \mathrm{~h}$ with or without IGF-I $(100 \mathrm{ng} / \mathrm{ml})$, forskolin $(10 \mu \mathrm{M})$ or PMA ( $10 \mathrm{~nm})$. The cells were then washed three times with fresh serum-free medium $(0.3 \% \mathrm{BSA})$ and were cultured for $20 \mathrm{~h}$ in the absence or presence of a second mitogenic agent as described in Figure 3 and Figure 4. $\left\{{ }^{3} \mathrm{H}\right\}$-Thymidine was then added in DME medium and its incorporation into DNA was measured $4 \mathrm{~h}$ later. The response to the treatment was similar regardless of

Table 1. Distribution of serum deprived HEC-1-A cells in the $G_{1}, S$ and $G_{2} / M$ phase of the cell cycle

\begin{tabular}{lc}
\hline Phase of the Cycle & Percentage of cells in cell cycle \\
\hline & Exponential growth \\
$\mathrm{G}_{1}$ & 32 \\
$\mathrm{~S}$ & 38 \\
$\mathrm{G}_{2} / \mathrm{M}$ & 29 \\
& Serum deprivation \\
$\mathrm{G}_{1}$ & 51 \\
$\mathrm{~S}$ & 12 \\
$\mathrm{G}_{2} / \mathrm{M}$ & 37 \\
\hline
\end{tabular}

HEC-1-A cells were grown to confluency and subcultured into 24 well plates $(50000$ cells $/$ well $)$. The cells were then incubated in the absence $(0.3 \% \mathrm{BSA})$ or presence of $10 \% \mathrm{FBS}$ (exponential growth) and the distribution of cells in the cell cycle analysed through flow cytometry as described in the Materials and Methods section. These results are representative of six individual analyses with similar results. 
whether the cells were incubated with a treatment once for $24 \mathrm{~h}$ or incubated for two consecutive $24 \mathrm{~h}$ treatment periods (data not shown).

Pretreatment with forskolin (Figure 3) or PMA (Figure 4) for $24 \mathrm{~h}$ increased IGF-I stimulation of $\left[{ }^{3} \mathrm{H}\right]$-thymidine incorporation over controls or treatment with a single agent alone. The increase of IGF-I effects by PMA was marginal when compared to that produced by forskolin (Figures 3 and 4).

\section{Time course of forskolin and PMA priming on IGF-I stimulated $\left[{ }^{3} \mathrm{H}\right]$-thymidine incorporation}

Cells primed for $3 \mathrm{~h}$ (or more) with forskolin exhibited a significant $(P<0.01)$ increase in $\left[{ }^{3} \mathrm{H}\right]-$ thymidine incorporation in response to IGF-I treatment compared to control or either treatment alone (Table 3). However, when cells were primed with PMA for less than $24 \mathrm{~h},\left[{ }^{3} \mathrm{H}\right]$-thymidine incorporation seen was comparable to that of IGF-I alone. Therefore, a minimum priming period of $24 \mathrm{~h}$ with PMA was required to enhance IGF-I stimulated $\left[{ }^{3} \mathrm{H}\right]$-thymidine incorporation above $(P<0.01)$ that seen with either treatment alone (Table 3). The increased responsiveness to IGF-I, apparently due to an increase in the number of IGF-I receptors, was then examined. Cells that were preincubated with either treatment for less than $12 \mathrm{~h}$ did not exhibit an increase in the number of IGF-I receptors. However, the number of receptors increased $(P<0.01)$ in response to $12 \mathrm{~h}$ incubation with forskolin over control with binding capacities of 3.7 and $6.9 \mathrm{~nm}$ for control and forskolin, respectively (Figure 5a). Similarly, treatment with PMA induced a significant

Table 2. Dose effect of IGF-I, forskolin and PMA on $\left[{ }^{3} \mathrm{H}\right]$-thymidine incorporation by $\mathrm{HEC}-1-\mathrm{A}$ cells

\begin{tabular}{lcl}
\hline & & $\begin{array}{c}\text { Thymidine incorporation } \\
\text { into DNA }\end{array}$ \\
\cline { 2 - 3 } Treatment & Dose & \multicolumn{1}{c}{ dpm/well } \\
\hline IGF-1 $(\mathrm{ng} / \mathrm{ml})$ & 0 & $1741 \pm 36$ \\
& 0.1 & $1788 \pm 160$ \\
& 1 & $1851 \pm 180$ \\
Forskolin $(\mu \mathrm{M})$ & 10 & $2508 \pm 160^{*}$ \\
& 100 & $2689 \pm 190^{*}$ \\
& 0 & $1553 \pm 89$ \\
& 0.1 & $1683 \pm 95$ \\
PMA $(\mathrm{nm})$ & 1 & $2709 \pm 125^{*}$ \\
& 10 & $3304 \pm 127^{*}$ \\
& 100 & $1609 \pm 76$ \\
& 0 & $1614 \pm 82$ \\
& 0.1 & $2415 \pm 94^{*}$ \\
& 1 & $2420 \pm 103^{*}$ \\
& 10 & $2288 \pm 171^{*}$ \\
\hline
\end{tabular}

HEC-1-A cells were incubated with the indicated concentrations of IGF-l, forskolin or PMA for $24 \mathrm{~h}$. During the last $4 \mathrm{~h}$ of the incubation, the cells were also exposed to $\left[{ }^{3} \mathrm{H}\right]$-thymidine. The incorporation of $\left[{ }^{3} \mathrm{H}\right]$-thymidine was measured as described in the Materials and Methods section. Data shown are the mean $\pm \mathrm{SEM}$ per well in replicates of four. ${ }^{*} P<0.01 v$. control. 


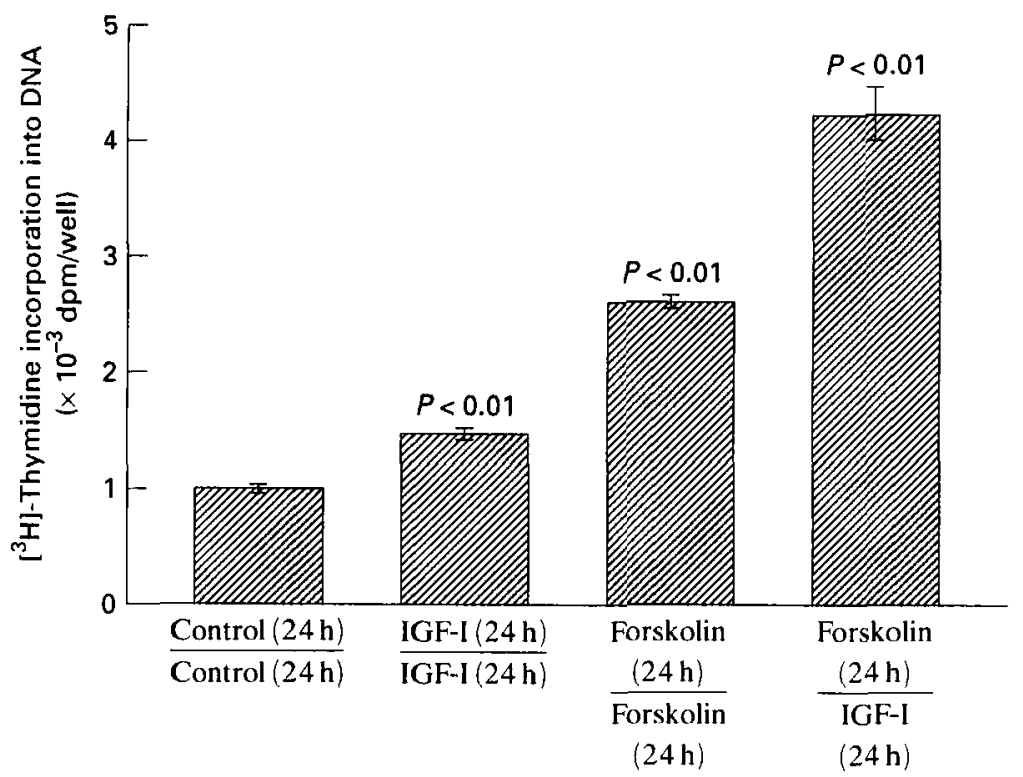

Figure 3. Effect of forskolin pre-incubation of HEC-1-A cells in IGF-I stimulation of $\left[{ }^{3} \mathrm{H}\right]$-thymidine incorporation. The cells were preincubated in the absence or presence of either IGF-I $(100 \mathrm{ng} / \mathrm{ml})$ or forskolin $(10 \mu \mathrm{M})$ for $24 \mathrm{~h}$. At the end of this incubation, the cells were washed three times and incubated for an additional $24 \mathrm{~h}$ with the treatments indicated at the bottom of each bar. $\left[{ }^{3} \mathrm{H}\right]$-Thymidine incorporation was measured during the last $4 \mathrm{~h}$ of the $24 \mathrm{~h}$ period as described in the Materials and Methods section. The results shown are the mean \pm SEM for well in replicates of six. The $P$ values denote significant differences when compared to controls.

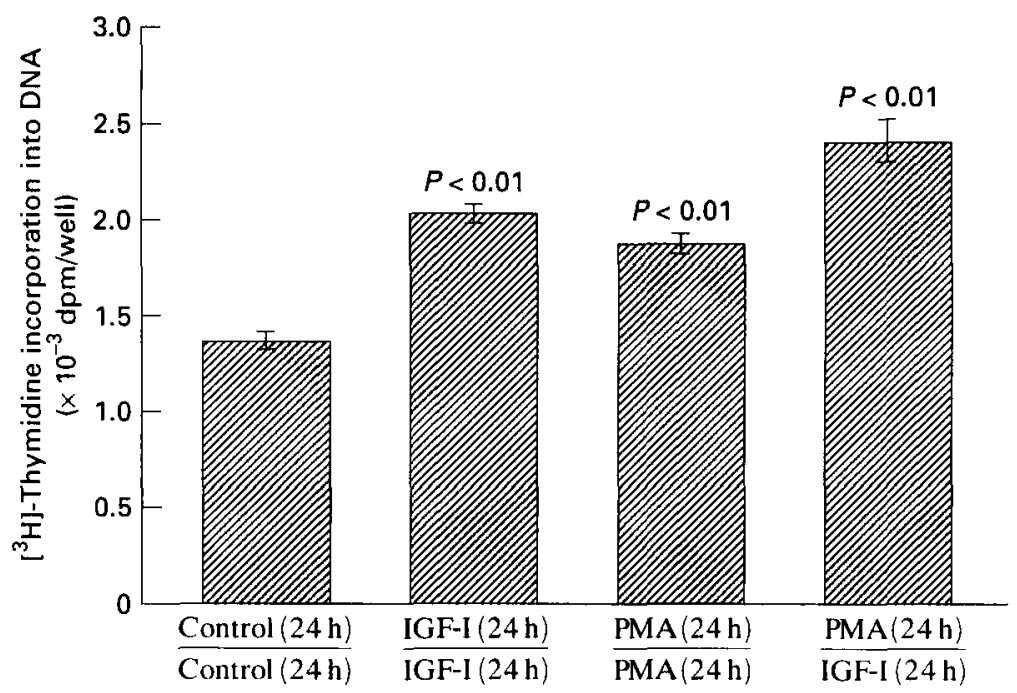

Figure 4. Effect of preincubation of HEC-1-A cells with PMA on the subsequent response of $\left[{ }^{3} \mathrm{H}\right]$-thymidine incorporation to IGF-I. The cells were preincubated in the absence or presence of either IGF-I $(100 \mathrm{ng} / \mathrm{ml})$ or PMA $(10 \mathrm{ng} / \mathrm{ml})$ or PMA $(10 \mathrm{nM})$ for $24 \mathrm{~h}$. At the end of this incubation, the cells were washed three times and incubated for an additional $24 \mathrm{~h}$ in the presence of the treatments indicated at the bottom of each bar. $\left[{ }^{3} \mathrm{H}\right]$-Thymidine incorporation was measured as for Figure 3 . The $P$ values denote significant differences when compared to controls. 
Table 3. Effect of forskolin and PMA priming on IGF-I time course of DNA synthesis in HEC-1-A cells

\begin{tabular}{|c|c|c|c|c|c|}
\hline \multicolumn{2}{|c|}{ Incubation } & \multicolumn{4}{|c|}{ Thymidine Incorporation into DNA (dpm/well) } \\
\hline First & Second & $3 \mathrm{~h}$ & $6 \mathrm{~h}$ & $12 \mathrm{~h}$ & $24 \mathrm{~h}$ \\
\hline Control & Control & $1615 \pm 129$ & $1374 \pm 139$ & $1530 \pm 67$ & $1477 \pm 286$ \\
\hline Forskolin & Forskolin & $3130 \pm 113^{*}$ & $3229 \pm 138^{*}$ & $3427 \pm 160^{*}$ & $3631 \pm 358^{*}$ \\
\hline IGF & IGF-1 & $2053 \pm 93^{*}$ & $2241 \pm 125^{*}$ & $2580 \pm 178^{*}$ & $2710 \pm 192^{*}$ \\
\hline Forskolin & IGF-I & $4725 \pm 149^{*}$ & $4836 \pm 123^{*}$ & $5523 \pm 187^{*}$ & $6028 \pm 117^{*}$ \\
\hline Control & Control & $1509 \pm 86$ & $1474 \pm 148$ & $1495 \pm 82$ & $1518 \pm 124$ \\
\hline PMA & PMA & $2140 \pm 142^{*}$ & $2160 \pm 172^{*}$ & $2322 \pm 152^{*}$ & $2391 \pm 76^{*}$ \\
\hline IGF-I & IGF-I & $2757 \pm 116^{*}$ & $2830 \pm 140^{*}$ & $2874 \pm 116^{*}$ & $2964 \pm 101^{*}$ \\
\hline PMA & IGF-I & $2094 \pm 156^{*}$ & $2241 \pm 196^{*}$ & $2473 \pm 128^{*}$ & $3672 \pm 124^{*}$ \\
\hline
\end{tabular}

HEC-1-A cells were first preincubated in the presence of either IGF-I $(100 \mathrm{ng} / \mathrm{ml})$ forskolin $(10 \mu \mathrm{M})$, or PMA ( $10 \mathrm{~nm}$ ) as indicated at the left of each row for 3,6,12 and $24 \mathrm{~h}$ as indicated at the top of each column. At the end of this incubation, the cells were treated for a second $20 \mathrm{~h}$ period in the presence of the agents indicated at the left of each row and exposed for an additional $4 \mathrm{~h}$ to $\left[{ }^{3} \mathrm{H}\right]$-thymidine. The incorporation of $\left[{ }^{3} \mathrm{H}\right]$-thymidine was measured as described in the Materials and Methods section. Data shown are the mean \pm SEM per well in replicates of four. ${ }^{*} P<0.01 v$. untreated control.

$(P<0.01)$ increase in the number of receptors with binding capacities of 3.4 and $4.8 \mathrm{nM}$ for control and PMA, respectively (Figure $5 \mathrm{~b}$ ). The $\mathrm{Kd}$, however, remained unchanged (1.77 $\mathrm{nm}$ ). Since PMA did not potentiate IGF-I effects until after $12 \mathrm{~h}$ of incubation, these results suggest that PMA enhances IGF-I response by increasing IGF-I receptors. In contrast, the effects of forskolin priming appear independent of a change in IGF-I receptor number.

\section{Effect of IGF-I priming on forskolin and PMA stimulated $\left[{ }^{3} \mathrm{H}\right]$-thymidine incorporation}

Since IGF-I is considered to be a progression factor and not a competence factor, experiments were performed to evaluate the effect of IGF-I priming on the mitogenic effects of forskolin (Figure 6a) and PMA (Figure 6b). To accomplish this objective, HEC-1-A cells were preincubated for $24 \mathrm{~h}$ with IGF-I $(100 \mathrm{ng} / \mathrm{ml})$. At the end of the pretreatment, the cells were washed twice and incubated for another $24 \mathrm{~h}$ in the absence or presence of either forskolin $(10 \mu \mathrm{M}$; Figure $6 \mathrm{a})$ or PMA (10 nM; Figure $6 \mathrm{~b})$. The results show that the stimulatory effect of forskolin and PMA on $\left[{ }^{3} \mathrm{H}\right]$-thymidine incorporation was abolished by IGF-I priming (Figure 6).

\section{Effect of 8-bromo-cAMP on $\left[{ }^{3} \mathrm{H}\right]$-thymidine incorporation}

The specificity of forskolin in enhancing IGF-I effects was then evaluated. Since forskolin acts by increasing intracellular levels of cAMP, the effect of pretreatment with 8-bromo-cAMP in enhancing the effect of IGF-I on $\left[{ }^{3} \mathrm{H}\right]$-thymidine incorporation was examined. When the cells were treated with 8-bromo-cAMP alone, $\left[{ }^{3} \mathrm{H}\right]$-thymidine incorporation by the HEC-1-A cells was increased significantly $(P<0.01)$. Pretreatment with 8 -bromo-cAMP enhanced $(P<0.01)$ the effects of IGF-I on $\left[{ }^{3} \mathrm{H}\right]$-thymidine incorporation to levels above those observed with control or either treatment alone (Figure 7).

\section{Effect of $4 \alpha$ PDD and OAG on $\left[{ }^{3} \mathrm{H}\right]$-thymidine incorporation}

Since PMA has been reported to activate protein kinase $\mathrm{C}$ in several tissues and since diacylglycerols are known to be an intracellular activator of this enzyme, the specificity of PMA in 

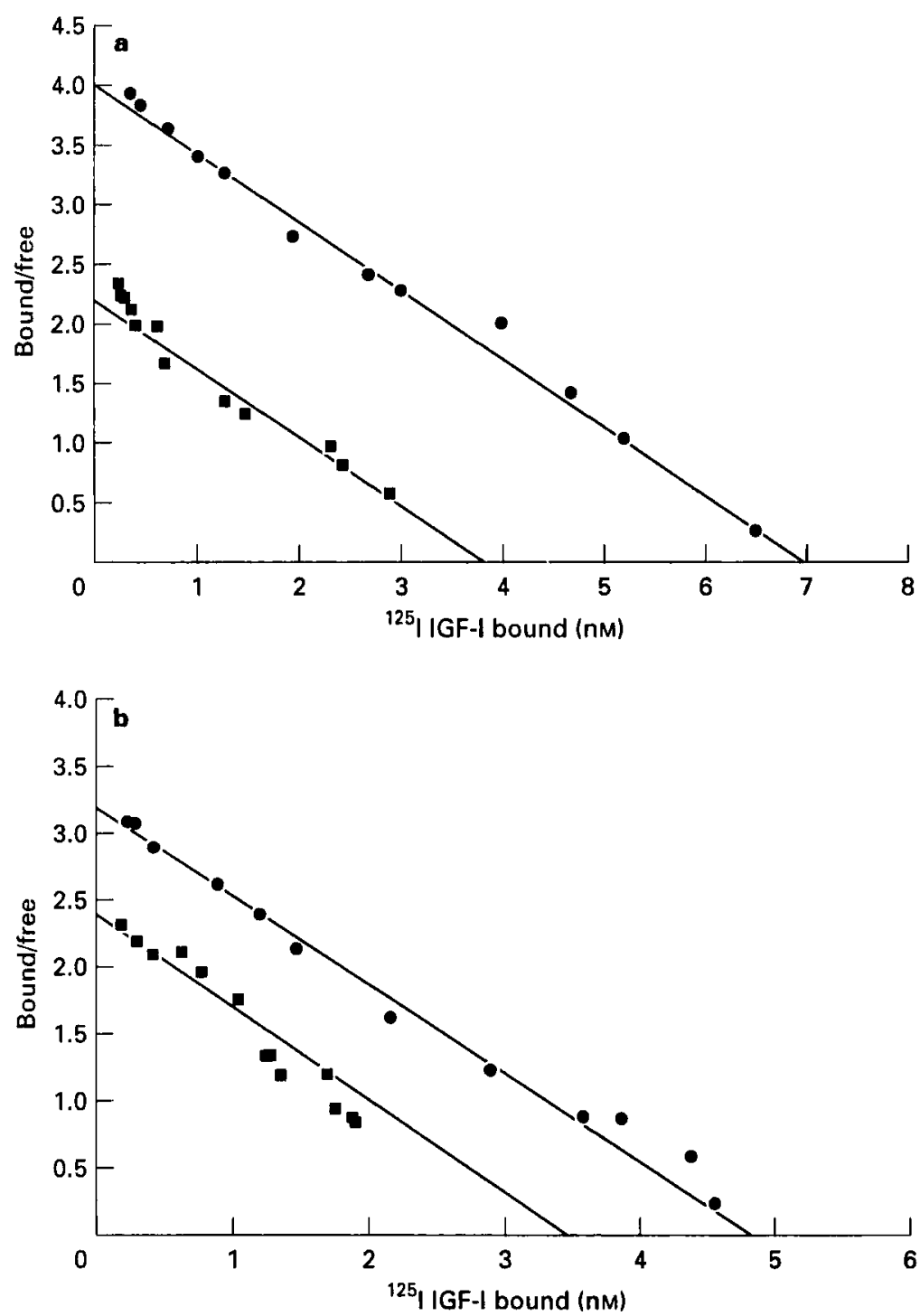

Figure 5. Comparison of IGF-I binding activity between a Control ( $\mathbf{a}$ )and Forskolin $(\bullet)(10 \mu \mathrm{M})$ and b Control ( and PMA $(\bullet)(10 \mathrm{nM})$ treated HEC-1-A cells. The specific activity of ${ }^{125}$ I-IGF-I was adjusted to $25000 \mathrm{cpm} / \mathrm{ng}$ protein by the addition of unlabelled IGF-I. The cells were preincubated in the absence or presence of either Forskolin $(10 \mu \mathrm{M})$ or PMA $(10 \mathrm{nM})$ for $12 \mathrm{~h}$. At the end of this incubation, the cells were incubated with various concentrations of ${ }^{125} \mathrm{I}-\mathrm{IGF}-\mathrm{I}(1-100 \mathrm{ng} / \mathrm{ml})$ for $16 \mathrm{~h}$ at $4^{\circ} \mathrm{C}$. To determine nonspecific binding, incubations were performed in the presence or absence of unlabelled IGF-I $(200 \mathrm{ng} / \mathrm{ml})$. The data were transformed into Scatchard plots. The values in the ordinate represent percent of bound over free.

enhancing the effects of IGF-I on $\left[{ }^{3} \mathrm{H}\right]$-thymidine incorporation was determined. The cells were pretreated with diacylglycerol, OAG, and the non-tumour promoting phorbol ester $4 \alpha$ PDD. When the cells were treated with $4 \alpha$ PDD alone (10 nM), there was no increase in $\left[{ }^{3} \mathrm{H}\right]$-thymidine incorporation (Figure 8). When cells were pretreated with $4 \alpha$ PDD followed by IGF-I, there was no increase in $\left[{ }^{3} \mathrm{H}\right]$-thymidine incorporation over that produced by IGF-I alone (Figure 8 ). OAG 

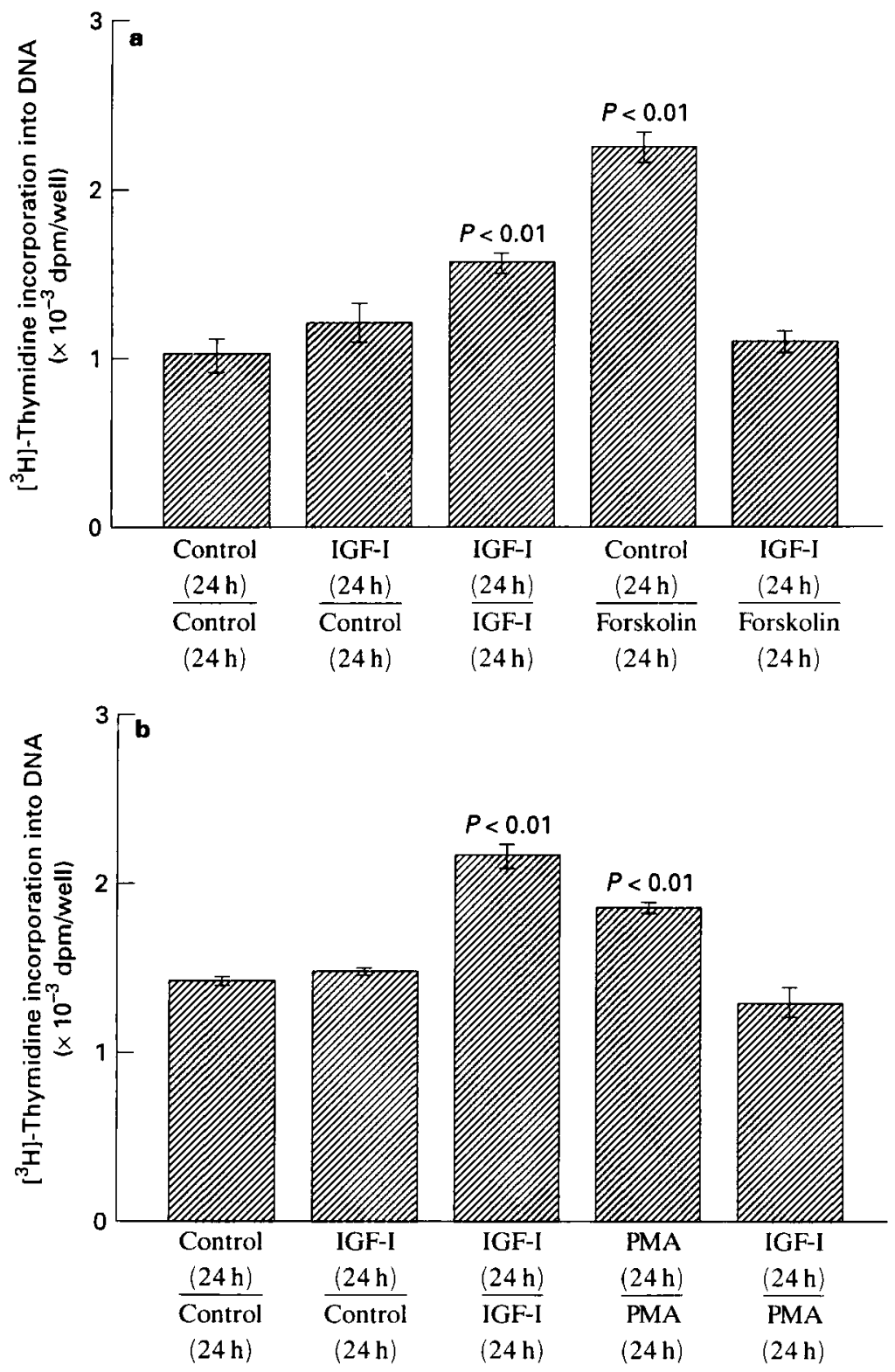

Figure 6. Effect of preincubation of HEC-1-A cells with IGF-I on a forskolin and b PMA stimulation of $\left[{ }^{3} \mathrm{H}\right]$-thymidine incorporation. The cells were preincubated in the absence or presence of either IGF-I $(100 \mathrm{ng} / \mathrm{ml})$, forskolin $(10 \mu \mathrm{M})$, or PMA $(10 \mathrm{nM})$ for $24 \mathrm{~h}$. At the end of this incubation, the cells were washed three times and incubated for an additional $24 \mathrm{~h}$ with the treatments indicated at the bottom of each bar. $\left[{ }^{3} \mathrm{H}\right]$-Thymidine incorporation was measured as described for Figure 3 . The $P$ values denote significant differences when compared to controls.

$(1 \mu \mathrm{M})$ alone increased $(P<0.01)\left[{ }^{3} \mathrm{H}\right]$-thymidine incorporation (Figure 8) and enhanced $(P<0.01)$ the effects of IGF-I (Figure 8$)$. The increase in $\left[{ }^{3} \mathrm{H}\right]$-thymidine incorporation in OAG pretreated cells stimulated with IGF-I was slightly higher $(P<0.05)$ than that produced by either IGF-I or OAG alone (Figure 8).

C 1995 Blackwell Science Ltd, Cell Proliferation, 28, 121-136. 


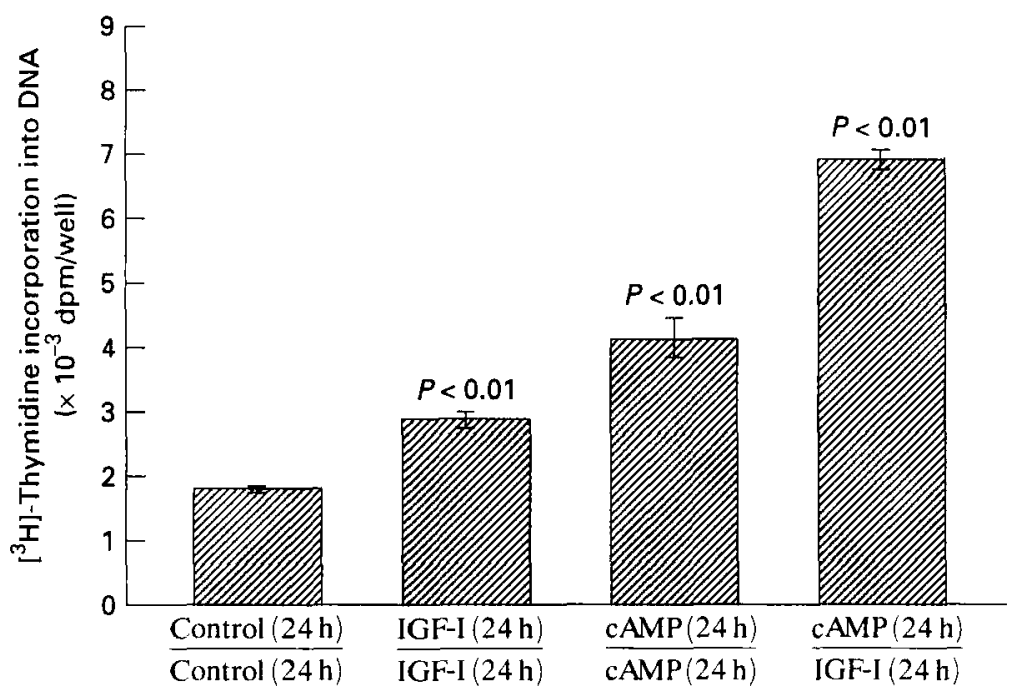

Figure 7. Effect of preincubation of HEC-1-A cells with 8-bromo-cAMP on the subsequent response to IGF-I. The cells were preincubated in the absence or presence of either IGF-I $(100 \mathrm{ng} / \mathrm{ml})$ or 8 -bromo-cAMP $(100 \mu \mathrm{M})$ for $24 \mathrm{~h}$. At the end of this incubation, the cells were washed three times and incubated for an additional $24 \mathrm{~h}$ in the presence of the treatments indicated at the bottom of each bar. $\left[{ }^{3} \mathrm{H}\right]-\mathrm{Thymidine}$ incorporation was measured as described for Figure 4. The $P$ values denote significant differences when compared to controls.

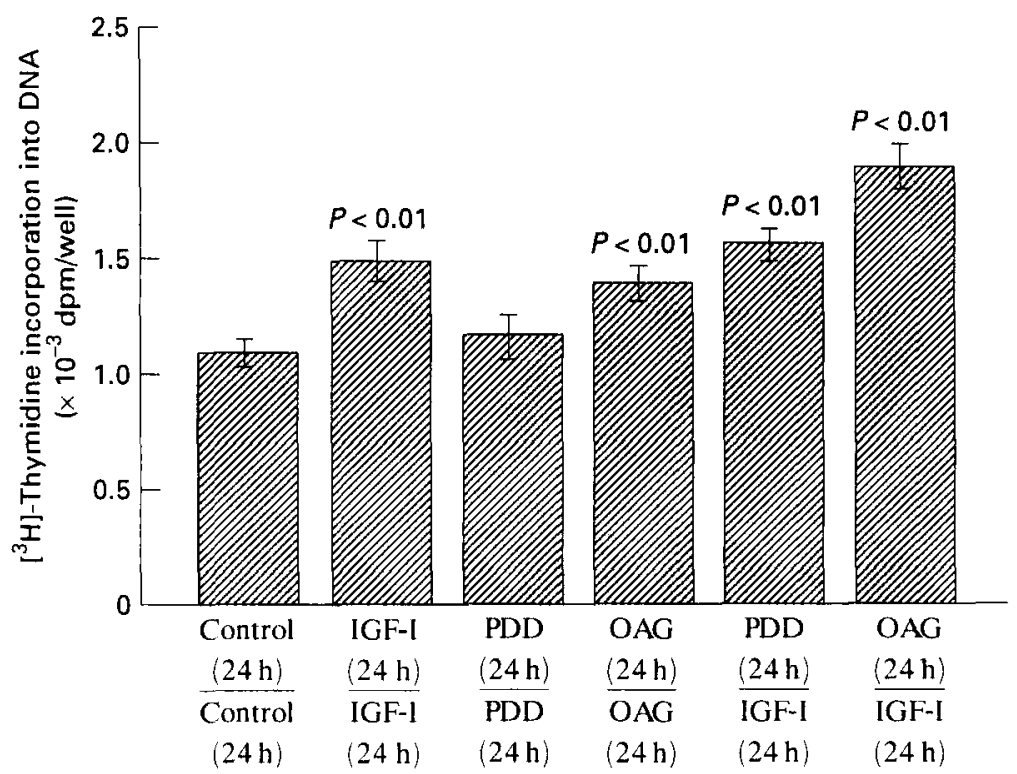

Figure 8. Effect of preincubation of HEC-1-A cells with $4 \alpha$ PDD and OAG on the subsequent response to IGF-I. The cells were preincubated in the absence or presence of either $1 G F-1(100 \mathrm{ng} / \mathrm{ml})$, PDD (10 $\mathrm{nm})$, or OAG $(1 \mu \mathrm{M})$ for $24 \mathrm{~h}$. At the end of this incubation, the cells were washed and incubated for an additional $24 \mathrm{~h}$ in the presence of the treatments indicated at the bottom of each bar. $\left[{ }^{3} \mathrm{H}\right]$-Thymidine incorporation was measured as described for Figure 4 . The $P$ values denote significant differences when compared to controls. 
Table 4. Effect of forskolin and PMA priming on IGF-I stimulation of cell proliferation

\begin{tabular}{llc}
\hline \multicolumn{2}{c}{ Incubation } & \\
\hline First & Second & Cell number/well \\
\hline Control & Control & $58493 \pm 3438$ \\
IGF-I & IGF-I & $83544 \pm 6842^{*}$ \\
Forskolin & Forskolin & $103633 \pm 5382^{*}$ \\
PMA & PMA & $74209 \pm 4862^{*}$ \\
Forskolin & IGF-I & $143573 \pm 10893^{*}$ \\
PMA & IGF-I & $100206 \pm 8532^{*}$ \\
\hline
\end{tabular}

Effect of forskolin and PMA priming on IGF-I stimulated cell proliferation. The cells were incubated in the absence or presence of either IGF-I $(100 \mathrm{ng} / \mathrm{ml})$, forskolin $(10 \mu \mathrm{M})$, or PMA (10 nM) for $24 \mathrm{~h}$. At the end of this period, the cells were washed three times and incubated for an additional $24 \mathrm{~h}$ in the presence of the treatments indicated far left of each row. Cells were harvested and counted as described in the Materials and Methods section. The results shown are the mean $\pm \mathrm{SEM}$. The numbers were rounded to the nearest hundred. ${ }^{*} P<0.01 v$. untreated control.

\section{Forskolin and PMA priming effect on IGF-I induced cell proliferation}

The effects of forskolin and PMA on IGF-I mediated increase in $\left[{ }^{3} \mathrm{H}\right]$-thymidine incorporation was further confirmed by determining the cell number. Forskolin and PMA enhanced the effects of IGF-I on cell proliferation $(P<0.01)$ above their respective treatment alone (Table 4$)$.

\section{DISCUSSION}

Although the effect of $c A M P$ or PKC on cell proliferation are not restricted to the $G_{10}-S$ transition phase, the present study focused on this part of the cell cycle, since the purpose of the study was to examine the effects of forskolin and PMA priming on IGF-I stimulation of thymidine incorporation and cell proliferation. The results suggest that forskolin and PMA may act beyond the $G_{0}$ phase to enhance IGF-I effects in HEC-1-A cell proliferation. These observations are supported by the results obtained with immunofluorescence staining, using the PCNA monoclonal antibody and flow cytometric analysis. The proliferating cell nuclear antigen is a $36 \mathrm{kDa}$ protein that has been identified as an auxiliary protein of DNA polymerase $\delta$ (Bravo et al. 1987). The enzyme activity increases through $G_{1}$, peaks at $G_{1} / S$ phase interface and decreases through $G_{2}$, reaching virtually undetectable levels by immunocytochemical methods in $M$ and $G_{0}$ phase of the cell cycle (Morris \& Mathews 1989). The granular staining observed in our studies was consistent with that reported in other cell systems (Coltrera \& Gown 1991). The absence of immunofluorescence in our controls and its presence in cells incubated with the monoclonal anti PCNA antibody demonstrate that PCNA is expressed in HEC-1-A cells, and the observations are consistent with reports showing that cancer cells do not enter the $G_{0}$ phase of the cell cycle. These results were further confirmed using an antibody against $\mathrm{Ki}-67$, a known cell cycle specific antigen. Thus in HEC-1-A cells, regulatory growth factors act predominantly in the $\mathrm{G}_{1} / \mathrm{S}$ phase 
and do not potentiate growth factor response by recruiting cells from their quiescent state. It is also conceivable that competence factors act at the $\mathrm{G}_{2} / \mathrm{M}$ transition phase of the cell cycle.

The absence of unstained cells also implies that none of the cells were in the $M$ phase of the cell cycle. Alternatively, PCNA staining may not be the best approach to identify cells that are in the $\mathrm{M}$ phase. However, the immunofluorescence staining was performed only $24 \mathrm{~h}$ following the initial plating. The doubling time for HEC-1-A cells is approximately $52 \mathrm{~h}$ (Kuramoto et al. 1972). In the present study, following $48 \mathrm{~h}$ incubation, the number of untreated cells increased only $16 \%$ from their initial plating density of approximately 50000 cells (Table 4), suggesting that serum deprivation decreases their growth rate significantly. Thus, the possibility that none of the cells were in the M phase, when the cells were harvested for the PCNA analysis, cannot be ruled out. Further studies will examine this possibility.

The finding that a higher percentage of cells exist in the $G_{2} / M$ phase of the cycle compared to the $S$ phase (Table 1) may suggest that the factors that act at the $G_{2} / M$ transition phase to stimulate mitosis are absent and the transition of the cells slows down when plated in a serum-free media. Alternatively, the apparent increase of cells present in the $G_{2} / M$ transition phase could reflect cell doublets from the $G_{1}$ phase of the cycle contaminating the $G_{2} / M$ peak analysed by the flow cytometer. Further studies are needed in order to examine this possibility.

Each treatment alone was able to increase cell replication of endometrial adenocarcinoma cell line HEC-1-A. Moreover, forskolin, and to a lesser extent, PMA enhanced the mitogenic response of the HEC-1-A cell line to IGF-I. The cAMP dependent pathway was responsible for increasing the mitogenic response of the forskolin primed cells to IGF-I, as the effect of forskolin was reproduced by the direct addition of 8-bromo-cyclic AMP. The mitogenic effect produced by PMA was also mimicked by exposing the cells to the diacylglycerol analog OAG, a known activator of protein kinase $C$, but not by its inactive analog, $4 \alpha$ PDD. This suggests that protein kinase $\mathrm{C}$ mediates the effects of PMA in the mitogenic response of the cells to IGF-I. Although PMA seems to mediate this effect by increasing the number of IGF-I receptors, forskolin may exert its effects by regulating intracellular post-receptor events. It is reasonable, therefore, to suggest that the effects of cAMP, and possibly protein kinase $\mathrm{C}$ dependent pathways, regulate early events of the cell cycle in transformed endometrial HEC-1-A cells. The results suggest that the cAMP, and possibly the protein kinase $C$ pathway, may enhance or increase the expression of genes present during the $G_{1}$ phase for the synthesis of enzymes involved in DNA synthesis during the $S$ phase. Conversely, IGF-I may exert its function either at the $G_{1} / S$ boundary or early during the onset of DNA synthesis. In this context, Rozengurt (1982) has shown that cyclic AMP analogues act in early $G_{1}$ phase of the cell cycle to potentiate the effects of insulin in quiescent Swiss $3 \mathrm{~T} 3$ cells. It has also been shown that early events of the S phase in CHO cells are mediated by other exogenous factors (Dijkwel \& Hamlin 1992). Our results support the observations of Tay et al. (1991) that in cancer cells the $G_{1}$ phase of the cell cycle represents a point of slow growth or a restriction point that can be overcome by growth promoting agents. Thus, although numerous studies have shown that competence factors such as cAMP or protein kinase $\mathrm{C}$ act in nontransformed cells to recruit them from the $G_{0}$ phase into the cell cycle, our study is the first one to show that in cancer cells these competence factors may act at the $G_{1}$ phase of the cycle to enhance their response to progression factors such as IGF-I.

The stimulatory effect of cAMP on $\left[{ }^{3} \mathrm{H}\right]$-thymidine incorporation was much greater than that produced by protein kinase $\mathrm{C}$ stimulating agents. Similar effects have been reported for FRTL-5 cells, which respond highly to forskolin but little to tetradecanoyl phorbol 12-myristyl, 13-acetate (Colleta et al. 1987). These results suggest that, compared to the protein kinase $C$ pathway, the cAMP pathway could play a more prominent role in DNA synthesis of some endocrine cells. 
The stimulatory effect of forskolin and PMA on $\left[{ }^{3} \mathbf{H}\right]$-thymidine incorporation was abolished when the cells were preincubated with IGF-I alone, which is consistent with similar effects reported for FRTL-5 cells (Takahashi et al. 1990). These results suggest that, in addition to acting as a progression factor, IGF-I may inhibit the effect of the cAMP and protein kinase C dependent pathway on DNA synthesis depending on the sequence of events.

Although the mechanisms by which the mitogenic effects of IGF-I are enhanced by forskolin and PMA are not well understood, recent evidence suggests that the cAMP dependent pathway interacts with the IGF-I receptor to increase tyrosine phosphorylation (Aaronson 1991, Sibley et al. 1988, Ullrich \& Schlessinger 1990). Studies on insulin receptors in endothelial cells have also shown that protein kinase $\mathrm{C}$ increases phosphorylation of the insulin receptor (Hachiya et al. 1987). Other possibilities include changes in the structure and organization of cytoskeletal proteins and alterations in gene expression (Houslay 1991, Schimke 1984). In addition, recent studies have suggested that short pulses of growth factors can increase the response of cells to IGF-I stimulation by either increasing the number of IGF-I receptors or by providing a new substrate for the activated receptor (Youshinouchi \& Baserga 1993).

Our results suggest that cAMP may play a prominent role in the proliferation of HEC-1-A cells. Thus, cAMP, and to a lesser extent, protein kinase $C$ responsive events, may mediate the biological actions responsible for enhancing the effect of IGF-I in the proliferation of transformed endometrial tumour cells by acting at the $G_{1}$ phase of the cell cycle. We conclude that multiple mitogenic pathways converge to potentiate the proliferation of endometrial adenocarcinoma cells.

\section{ACKNOWLEDGEMENTS}

The authors would like to thank Dr Alan C. Menge for his expertise on the immunofluorescence staining of HEC-1-A cells. This study was supported in part by the Catherine Brown Fund and the University of Michigan Cancer Institute. FT is a recipient of National Research Service Award F32 CA08710 from the National Cancer Institute. MLP is a recipient of American Cancer Society Clinical Oncology Fellowship 92-101-1.

\section{REFERENCES}

Aaronson SA. (1991) Growth factors and cancer. Science 254, 1146.

Bravo R, Frank R, Blundell PA, Macdonald BH. (1987) Cyclin/PCNA is the auxiliary protein of DNA polymerase-delta. Nature 326, 515 .

Chernausek SD, Beach DC, Banach W, Sperling MA. (1987) Characteristics of hepatic receptors for somatomedin-c/insulin-like growth factor-I and insulin in the developing human. $J$. Clin. Endocrinol. Metab. 64, 737.

Colleta G, Cirafici AM, Consiglio E, Vecchio G. (1987) Forskolin and a tumor promoter are able to induce c-fos and c-myc expression is normal, but not in a v-ras-transformed rat thyroid cell line. Oncogene Research 1, 459.

Coltrera MD, Gown AM. (1991) PCNA/Cyclin Expression and BrdU uptake define different subpopulations in different cell lines. J. Histochem. Cytochem. 39, 23.

Coppola D, Ferber A, Miura M, Sell. C, D'ambrosio, Rubin R, Baserga R. (1994) A functional insulin-like growth factor-I receptor is required for the mitogenic and transforming activities of the epidermal growth factor receptor. Mol. Cell. Biol. 14, 4588.

Dickson RB, LiPPMAN ME. (1987) Estrogenic regulation of growth and polypeptide growth factor secretion in human breast carcinoma. Endocr. Rev. 8, 29.

Dujwel PA, Hambin JL. (1992) Initiation of DNA replication in the dihydrofolate reductase locus is confined to the early $S$ phase period in $\mathrm{CHO}$ cells synchronized with the plant amino acid mimosine. Mol. Cell. Biol. 12, 3715. 
Hachiya H, Takayoma S, White MF, King GL. (1987) Regulation of insulin receptor internalization in vascular endothelial cells by insulin and phorbol ester. J. Biol. Chem. 262, 736.

HousL.AY MD. (1991) 'Crosstalk': a pivotal role for protein kinase $C$ in modulating relationships between signal transduction pathways. Eur. J. Biochem. 195, 9.

ImaI Y, Leung CKH, Friesen HG, Shiu RPC. (1982) Epidermal growth factor receptors and effect of epidermal growth factor on growth of human breast cancer cell in long-term tissue culture. Cancer Research 42, 4394.

Kuramoto H, Tamura S, Natake Y. (1972) Establishment of a cell line of human endometrial adenocarcinoma in vitro. Am. J. Obstet. Gynecol. 114, 1012.

Labarca C, Paigen K. (1982) A simple rapid and sensitive DNA assay procedure. Analyt. Biochem. 102, 344.

Menge AC, Mestecky J. (1993) Surface expression of secretory component HLA Class II DR antigen on glandular epithelial cells from human endometrium and two endometrial adenocarcinoma cell lines. $J$. Clin. Immunol. 13, 259.

Morris GF, Mathews MB. (1989) Regulation of proliferating cell nuclear antigen during the cell cycle. J. Biol. Chem. 264, 13856.

MurPhy LJ, Murphy LC, Friesen HG. (1987) Estrogen induces insulin-like growth factor-I expression in the rat uterus. Mol. Endocrinol. 1, 445.

Olashaw NE, Pledger WJ. (1988) Epidermal growth factors stimulates formation of inosital phosphates in Balb/C 3T 3 cells pretreated with cholera toxin and isobutylxanthine. J. Biol. Chem. 263, 1111 .

Pearl ML. Talavera F, Gretz HF, ill, Roberts JA, Menon KMJ. (1993) Mitogenic activity of growth factors in the human endometrial carcinoma cell lines HEC-1-A and KLE. Gynecologic Oncology 49, 325.

Perkonen F, Nyman T, Rutman EM. (1991) Human endometrial adenocarcinoma cell lines HeC-1-b and KLE secrete insulin-like growth factor binding protein-1- and contain IGF-I receptors. Mol. Cell. Endocrinol. 75, 81 .

Pietrzkowski Z, Sell C, Lammers R, Ullrich A, Baserga R. (1992) Roles of Insulin like growth factor 1 (IGF-I) and the IGF-I receptor in epidermal growth factor stimulated growth of 3 T3 cells. Mol. Cell. Biol. $12,3883$.

RozENGUR' E. (1982) Synergistic stimulation of DNA synthesis by cyclic AMP derivatives and growth factors in mouse 323 cells. J. Cell. Physiol. 112, 243.

SCHIMKE RT. (1984) Gene amplification in cultured animal cells. Cell 37, 705.

Sei.l. C, Ptasznik A, Chang C-D, Swantek J, Cristofalo VJ, Baserga R. (1993) IGF-I receptor levels and the proliferation of young and senescent human fibroblast. Biochem. Biophys. Res. Commun. 194, 599.

Sibley DR, Benovic JL, Caron MG, Lefkowitz RJ. (1988) Phosphorylation of cell surface receptors: a mechanism for regulating signal transduction pathways. Endocrine Reviews 9, 38.

TAKAHASH S, CONTI M, VAN WYK JJ. (1990) Thyrotropin potentiates of insulin like growth factor I dependent deoxiribonucleic acid synthesis in FRTL-5 cells: mediation by an autocrine amplification factor(s). Endocrinology 126, 736.

Talavera F, Pearl ML, Roberts Ja, Menon KMJ. (1992) Effect of the protein kinase $C$ agonist phorbol 12-myristate 13-acetate (PMA) and adenylate cyclase agonist forskolin in the mitogenic activity of endometrial carcinoma cell line HEC-1-A. Soc. Gyn. Invest. 39, 462A.

Talavera F, Reynolds RK, Roberts JA, Menon KMJ. (1990) Insulin-like growth factor-1 receptors in normal and neoplastic human endometrium. Cancer Res. 50, 3019.

TaY DLM, Bhathal PS, Fox RM. (1991) Quantitation of $G_{0}$ and $G_{1}$ Phase cells in primary carcinomas: Antibody to $M_{1}$ subunit of ribonucleotide reductase shows $G_{1}$ phase restriction point block. J. Clin. Invest. 87, 519 .

Tramontano D, Moses AC, Venezioni BM, Ingbar SH. (1988) Adenosine 3'5'-monphosphate mediates both the mitogenic effect of thyrotropin and its ability to amplify the response to insulin-like growth factor I in FRTL 5 cells. Endocrinology 122, 127.

Tricoli JV, Rall LB, Karakous CP et al. (1986) Enhanced levels of insulin-like growth factor messenger RNA in human colon carcinoma and lipoarcomas. Cancer Research 46,6169.

Ullaich A, SCHLESSINGER J. (1990) Signal transduction by receptors with tyrosine kinase activity. Cell 61 , 203.

Youshinouchi M, BASERGa R. (1993) The role of the IGF-I receptor in the stimulation of cells by short pulses of growth factors. Cell Prolif. 26, 139. 